\title{
A new Aspidoras (Siluriformes: Callichthyidae) from rio Paraguaçu basin, Chapada Diamantina, Bahia, Brazil
}

\author{
Marcelo R. Britto*, Flávio C. T. Lima**, and Alexandre C. A. Santos***
}

During a recent ichthyological survey in Chapada Diamantina, Estado da Bahia, Brazil, a new, very distinctive Aspidoras was discovered in tributaries of the upper rio Paraguaçu. The new taxon differs from its congeners mainly in having: a poorlydeveloped pigmentation pattern, restricted to minute scattered blotches on dorsal region of head and body, but grouped in small, irregular blotches along the lateral body plate junction; four or five caudal vertebra, anterior to compound caudal centrum, with neural and haemal spines placed posteriorly, close to post-zygapophyses; and post-zygapophyses of the precaudal vertebrae without dorsal expansions connected with their respective neural spines. The new species shares with Aspidoras velites dorsolateral body plates not touching their counterparts dorsally, and infraorbital bones with reduced flanges that are restricted to the latero-sensory canal. Both of these are considered reductive character states, probably indicating a paedomorphic condition to both species. The new species is also compared to Aspidoras maculosus, a congener which bears the most similar color pattern and is geographically closest to the new species.

Durante um estudo recente sobre a ictiofauna da Chapada Diamantina, foi descoberta uma nova espécie de Aspidoras, bastante distinta morfologicamente de suas congêneres, em afluentes do alto rio Paraguaçu, Estado da Bahia, Brasil. O novo táxon difere das demais espécies de Aspidoras principalmente pela pigmentação pouco desenvolvida, restrita a minúsculas máculas espalhadas na região dorsal da cabeça e corpo, concentradas em pequenas manchas irregulares ao longo da junção das placas laterais; por apresentar as quatro a cinco últimas vértebras caudais anteriores ao centro caudal composto com os espinhos neurais e hemais situados posteriormente junto às pós-zigapófises; e pós-zigapófises das vértebras pré-caudais sem expansões dorsais unidas ao respectivo espinho neural. Além disso, a nova espécie compartilha com Aspidoras velites a condição em que as placas dorso-laterais não contatam suas contrapartes dorsalmente, e os ossos infra-orbitais reduzidos a pouco mais que o canal látero-sensorial, características redutivas, provavelmente indicando um estado de caráter pedomórfico para estas espécies. A nova espécie é ainda comparada a Aspidoras maculosus, congênere mais semelhante no padrão de colorido e também aquela mais próxima geograficamente.

Key words: Systematics, Aspidoras maculosus, Sand-dwelling, Paedomorphic characters.

\section{Introduction}

The genus Aspidoras Ihering includes 19 nominal species of catfishes that are generally found in shallow creeks of several river basins draining mainly the Brazilian Shield (Britto et al., 2002). Although the validity of some characters traditionally used to define Aspidoras, such as the size of the frontal fontanel and the presence of a parieto-supraoccipital fontanel had been questioned previously (Nijssen \& Isbrücker, 1976; Weitzman \& Balph, 1979), the monophyly of the genus was recently demonstrated through phylogenetic studies (Reis, 1998; Britto, 2003).

The increase in ichthyological samplings in Neotropical rivers in decades recently has brought many new taxa to science (Vari \& Malabarba, 1998; Schaefer, 1998; Reis et al., 2003). This assertion fits precisely for Aspidoras, which has 30\% of its species (including the new one presented herein) discovered in recent fish surveys, and described in the last eight years (Britto, 1998, 2000; Lima \& Britto, 2001; Britto et al., 2002).

\footnotetext{
* Museu Nacional, Universidade Federal do Rio de Janeiro, Quinta da Boa Vista, 20940-040 Rio de Janeiro, RJ, Brazil. e-mail: mrbritto2002@yahoo.com.br

** Museu de Zoologia da Universidade de São Paulo, Caixa Postal 42594, 04299-970 São Paulo, SP, Brazil. e-mail: fctlima@usp.br

*** Departamento de Ciências Biológicas, Universidade Estadual de Feira de Santana, Km 03, BR-116, 44031-460 Feira de Santana, BA, Brazil. e-mail: clister@ig.com.br
} 
The rio Paraguaçu is an eastern Brazilian coastal river basin which has its headwaters mostly on the eastern slope of Chapada Diamantina plateau, a relatively high massif (heights up to 2000 meters above sea level) of the Brazilian Shield. In the last few years, the region of the Chapada Diamantina has yielded several new fish species, including an entire assemblage of Trichomycteridae, the Copionodontinae (de Pinna, 1992: Campanario \& de Pinna, 2000) and interesting characids (Lima \& Gerhard, 2001; Zanata \& Akama, 2004; Malabarba et al., 2004). During a recent, broad fish survey conducted in this area, one of the authors (ACAS) collected a distinctive Aspidoras species that possesses several uncommon or unique features among the members of the family. We describe below this new species, and we suggest that some of those features might be related to a specialized lifestyle.

\section{Material and Methods}

Morphometric and meristic data were taken following Reis (1997), with the addition of the length of the ossified portion of pectoral spine, which was measured from the articulation between the spine and pectoral girdle to distal tip of spine. Measurements were obtained with calipers to $0.1 \mathrm{~mm}$. Counts of teeth and vertebrae were taken only from cleared-andstained (cs) specimens, which were prepared according to Taylor \& Van Dyke (1985). Vertebral counts include only free centra, with the compound caudal centra (preural $1+$ ural 1) counted as a single element. Lateral plate counts include all dorsolateral and ventrolateral plates, except for small, irregular plates on caudal peduncle. In the description, numbers in parentheses following each count represent the number of specimens with that value and counts indicated with an asterisk represent counts from the holotype. Nomenclature of latero-sensory canals follows Schaefer \& Aquino (2000), and that of preopercular pores follows Schaefer (1988). Osteological terminology follows Reis (1998), except for the use of parieto-supraoccipital instead of supraoccipital (Arratia \& Gayet, 1995), compound pterotic instead of pteroticsupracleithrum (Aquino \& Schaefer, 2002), and scapulocoracoid instead of coracoid (Lundberg, 1970), as adopted in Britto \& Lima (2003). Homologies of barbels follow Britto \& Lima (2003). Institutional abbreviations are: FMNH, Field Museum of Natural History, Chicago; MCP, Museu de Ciência e Tecnologia da Pontifícia Universidade Católica do Rio Grande do Sul, Porto Alegre; MNRJ, Museu Nacional da Universidade Federal do Rio de Janeiro; and MZUSP, Museu de Zoologia da Universidade de São Paulo, São Paulo.

Comparative material is listed in Lima \& Britto (2001) and Britto (2003). In addition, the following material was studied: Aspidoras maculosus Nijssen \& Isbrücker (measurements taken by P. Willink) FMNH 54808 (3), paratypes; FMNH 54809 (1), paratype; FMNH 54810, holotype; FMNH 78361 (2), paratypes; Corydoras lacerdai Hieronimus MNRJ 26017 (17, 4 cs); and Scleromystax sp. MCP 28729 (20, 3 cs); MCP 29299 (5, $1 \mathrm{cs})$.

\section{Aspidoras psammatides, new species}

Figs. 1-5

Holotype. MNRJ 28407 (25.7 mm SL) Brazil, Estado da Bahia, município de Lençóis, rio Caldeirão, 12³9'33"S 4122’12"W; A. C. A. Santos, 6 Nov 1999.

Paratypes. All from Brazil, Estado da Bahia, município de Lençóis: MNRJ 21269 (51, 15.4-27.8 mm SL); MZUSP 67194 (20, 17.1-27.6 mm SL); same data as holotype. MNRJ 21270 (26, 2 cs, 15.9-30.4 mm SL); MZUSP 67195 (20, 16.6-31.0 mm SL); rio Capivara, 12³7' 19"S 41'22'35"W; A. C. A. Santos, 13 Mar 1999. MNRJ 21708 (7, 14.4-21-2 mm SL) rio Roncador, $12^{\circ} 42^{\prime} 01^{\prime \prime S} 41^{\circ} 21^{\prime} 26^{\prime \prime W}$; A. C. A. Santos, 13 Mar 1999. MNRJ 21709 (50, 2 cs, 15.0-28.4 mm SL) rio Caldeirão, 12³9'33"S 41'22'12"W; A. C. A. Santos, 13 Mar 1999. MNRJ 21710 (18, 1 cs, 16.7-24.9 mm SL) rio Roncador, 12² $42^{\prime} 01^{\prime \prime S} 41^{\circ} 21^{\prime} 26^{\prime \prime W}$; A. C. A. Santos, 6 Nov 1999. MNRJ 21711 (47, 16.5-27.9 mm SL) rio Capivara, $12^{\circ} 37^{\prime} 19^{\prime \prime S} 41^{\circ} 22^{\prime} 35^{\prime \prime}$ W; A. C. A. Santos, $6 \mathrm{Nov}$ 1999. MNRJ 21712 (1, 23.2 mm SL) rio Ribeirão, 12³5'10"S 4122'57"W; A. C. A. Santos, 6 Nov 1999.

Diagnosis. Aspidoras psammatides differs from its congeners by the following exclusive features: poorly-developed pigmentation, restricted to minute scattered blotches on dorsal region of head and body, grouped in small, irregular blotches along lateral body plate junction ( $v s$. dense pigmentation, in marbled or striped pattern); four or five caudal vertebra (vs. only three vertebra) anterior to compound caudal centrum, with neural and haemal spines placed posteriorly, close to post-zygapophyses; minor least interorbital distance (19.9 - 27.8\% in HL vs. greater than $28 \%$ in HL); and postzygapophyses of precaudal vertebrae not showing dorsal expansions connected with its respective neural spine (vs. postzygapophyses connected with their respective neural spine).

Description. Morphometric data presented in Table 1. Head compressed with slightly convex dorsal profile; roughly triangular in dorsal view (Fig. 2). Snout rounded. Head profile convex from upper lip to vertical through middle of parietosupraoccipital; body slightly convex from that point to base of last dorsal-fin ray. Postdorsal-fin body profile slightly concave to adipose-fin spine; markedly concave from this point to caudal-fin base. Ventral profile of body slightly convex from isthmus to anal-fin origin; slightly pronounced between pectoral fins. Profile markedly concave from first anal-fin ray to caudal-fin base. Body elongated; roughly cylindrical in cross section at pectoral girdle, gradually becoming more compressed toward caudal fin.

Eye rounded, dorso-laterally on head; orbit delimited dorsally by frontal and sphenotic, ventrally by infraorbitals. Anterior and posterior nares close to each other, only separated by flap of skin. Anterior naris tubular. Posterior naris close to anterodorsal margin of orbit, separated from it by distance equal to naris diameter. Mouth small, subterminal, width nearly equal to bony orbit diameter. Maxillary barbel elongate, but not reaching anteroventral limit of gill opening. 


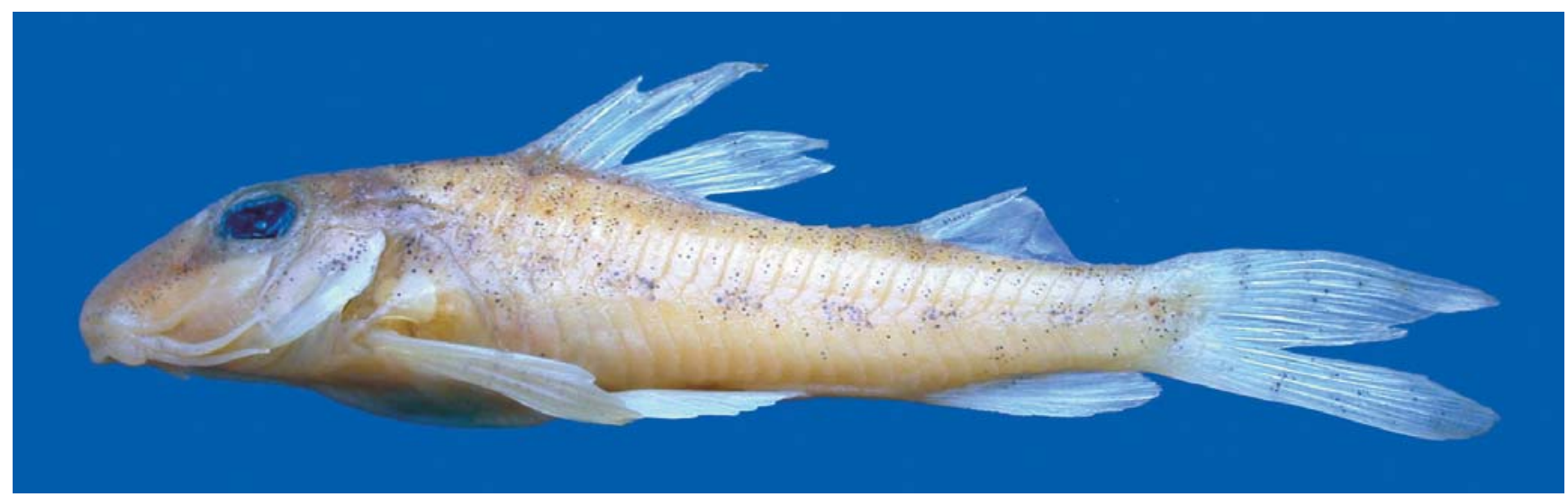

Fig. 1. Aspidoras psammatides, holotype, MNRJ 28407, $25.7 \mathrm{~mm} \mathrm{SL}$, Brazil, Estado da Bahia, município de Lençóis, rio Caldeirão.

Maxillary barbel slightly longer than outer mental barbel. Inner mental barbel fleshy. Small rounded papillae covering entire surface of all barbels, upper and lower lips, and isthmus. Gill membranes united to isthmus. Four branchiostegal rays covered by thick layer of skin; distal two rays united at their tips by branchiostegal cartilage. Teeth on upper pharyngeal tooth plate 28 (2) or 34 (1), and on fifth ceratobranchial 22 (1) or 24 (2).

Nasal, frontal, sphenotic, compound pterotic, and parietosupraoccipital visible externally, all covered by thin layer of skin and bearing minute scattered odontodes. Frontal fontanel elongate, ellipsoid, covered by thin layer of skin, and reaching anterior border of parieto-supraoccipital. Parietosupraoccipital fontanel round, located in the middle of bone Nasal slender, slightly curved laterally, mesial border contacting frontal and mesethmoid. Frontal roughly rectangular; anterior expansion in contact with nasal bone and mesethmoid, posterior portion contacting sphenotic and parieto-supraoccipital. Sphenotic trapezoid in shape, contact-

Table 1. Morphometric data of holotype and paratypes of Aspidoras psammatides.

\begin{tabular}{lccccc}
\hline & \multicolumn{4}{c}{ Paratypes (n= 51) } \\
\cline { 3 - 6 } & Holotype & mean & \multicolumn{3}{c}{ range } \\
\hline Standard length (mm) & 25.7 & 25.3 & 20.4 & - & 31.0 \\
& Percents of Standard length & & & \\
Depth of body & 21.5 & 19.8 & 16.9 & - & 23.5 \\
Predorsal distance & 45.6 & 44.6 & 41.4 & - & 47.6 \\
Prepelvic distance & 46.0 & 44.7 & 41.7 & - & 48.6 \\
Preanal distance & 77.7 & 76.2 & 70.7 & - & 82.6 \\
Preadipose distance & 78.3 & 78.3 & 71.0 & - & 82.0 \\
Length of dorsal spine & 13.2 & 12.7 & 10.5 & - & 15.0 \\
Length of pectoral spine & 14.3 & 13.4 & 10.5 & - & 17.5 \\
Length of adipose-fin spine & 9.4 & 10.6 & 6.9 & - & 13.5 \\
Depth of caudal peduncle & 8.7 & 9.0 & 7.5 & - & 10.1 \\
Dorsal to adipose distance & 21.7 & 23.2 & 14.8 & - & 28.8 \\
Length of dorsal-fin base & 16.0 & 16.0 & 12.7 & - & 21.9 \\
Maximum cleithral width & 9.1 & 11.6 & 8.7 & - & 22.3 \\
Head length & 35.4 & 37.0 & 34.7 & - & 40.5 \\
Length of maxillary barbel & 13.8 & 13.8 & 10.6 & - & 20.0 \\
& Percents of Head length & & & \\
Head depth & 60.0 & 57.3 & 34.2 & - & 63.2 \\
Least interorbital distance & 22.4 & 22.5 & 19.9 & - & 27.8 \\
Horizontal orbit diameter & 21.1 & 21.9 & 18.8 & - & 24.6 \\
Snout length & 47.0 & 47.2 & 40.0 & - & 54.4 \\
Least internareal distance & 17.8 & 18.4 & 10.9 & - & 24.9 \\
\hline
\end{tabular}

ing parieto-supraoccipital dorsally, compound pterotic posteriorly, and second infraorbital ventrally. Compound pterotic roughly pipe-shaped, with slender posterior expansion contacting first dorsal body plate dorsally, and first lateral-line ossicle posteriorly. Ventral margin of compound pterotic contacting opercle and cleithrum. Parieto-supraoccipital quadrangular with posterior expansion triangular and short, not reaching nuchal plate (Fig. 2).

Two narrow infraorbital bones nearly restricted to laterosensory canal, externally visible, covered by thin layer of skin. Both bearing few minute odontodes. First infraorbital with very short anterior expansion (flange; Fig. 3). Minute odontodes-bearing platelets dorsally on orbit. Opercle exposed, ovoid in shape and roughly elongate, with angular free border. Preopercle externally visible, slender and covered by thin layer of skin. Interopercle triangular, covered by thin layer of skin.

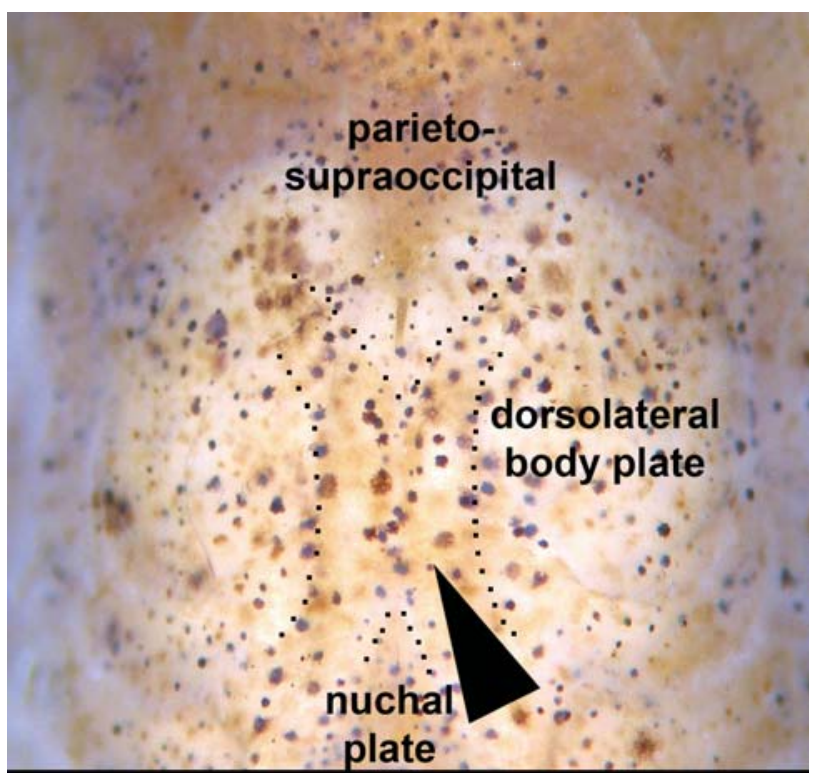

Fig. 2. Dorsal view of head of Aspidoras psammatides, holotype, MNRJ 28407, $25.7 \mathrm{~mm}$ SL. Arrow: naked groove between parieto-supraoccipital posterior process and nuchal plate. 


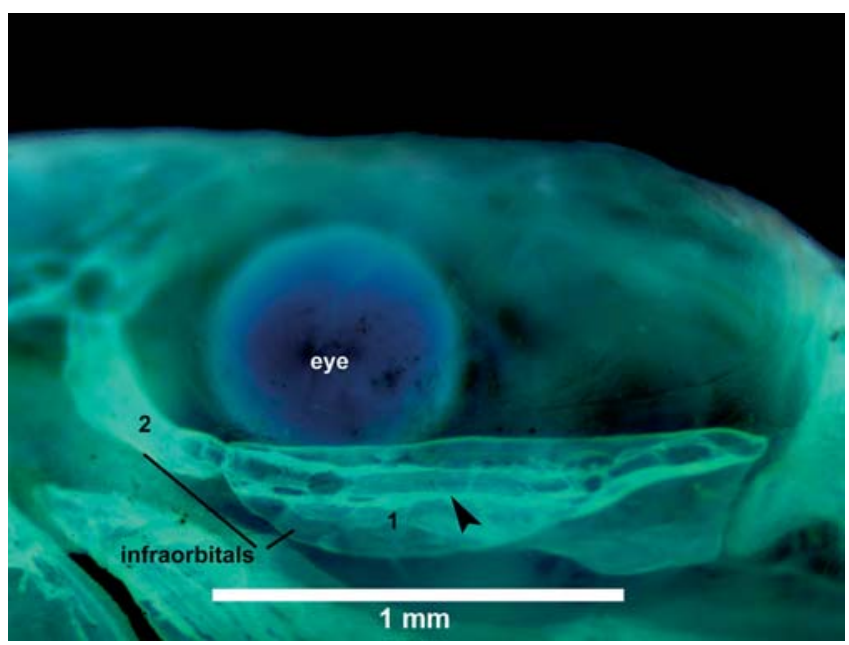

Fig. 3. Orbital region of Aspidoras psammatides, paratype, MNRJ 21709, $22.6 \mathrm{~mm}$ SL, right side. Arrow: latero-sensory canal.

Trunk lateral-line composed of one perforated dorsolateralbody plate and two laterosensory canals, reduced to small ossicles. Lateral-line canal entering neurocranium through compound pterotic, splitting posterior of sphenotic into pterotic and preoperculomandibular branches, each with single pore. Sensory canal continuing through compound pterotic, entering sphenotic as temporal canal, which splits into two branches: one branch giving rise to infraorbital canal, other branch entering frontal through supraorbital canal. Supraorbital canal with two branches: epiphyseal branch opening in frontal bone, and anterior branch running through nasal bone. Nasal canal with single opening at each end. Infraorbital canal running through entire second infraorbital, extending to infraorbital 1 and opening into two pores. Preoperculomandibular branch not connected to preoperculomandibular canal, which runs through entire preopercle with three openings, leading to pores 3,4 , and 5 , respectively.

Body plates with minute odontodes restricted to posterior margins. Nuchal plate exposed. Cleithrum exposed. Dorsolateral body plates between parieto-supraoccipital process and nuchal plate not touching counterparts, leaving narrow naked area; specimens less than $26.4 \mathrm{~mm}$ SL also shows naked area between last dorsal-fin ray and first preadipose platelet. Dorsolateral body plates $26(2), 27 *(24), 28$ (24), or 29 (2); ventrolateral body plates $24(19), 25^{*}(25)$, or $26(8)$; dorsolateral body plates along dorsal-fin base 6 (12) or $7 *$ (40); dorsolateral body plates from adipose fin to caudal-fin base 8 (2), 9 (8), 10* (23), 11 (18), or 12 (1); preadipose platelets 2 (1), 3 (11), $4 *(35), 5$ (4), or 6 (1). Precaudal vertebrae 7 (2) or 8 (3); caudal vertebrae 18 (5). Four to five caudal vertebra, anterior to compound caudal centrum, with neural and haemal spines placed posteriorly, close to post-zygapophyses (Fig. 4). Post-zygapophyses of precaudal vertebrae reduced, not showing dorsal expansions connected with respective neural spine (Fig. 5). Five (4) or seven (1) pairs of ribs, first pair conspicuously larger than others.

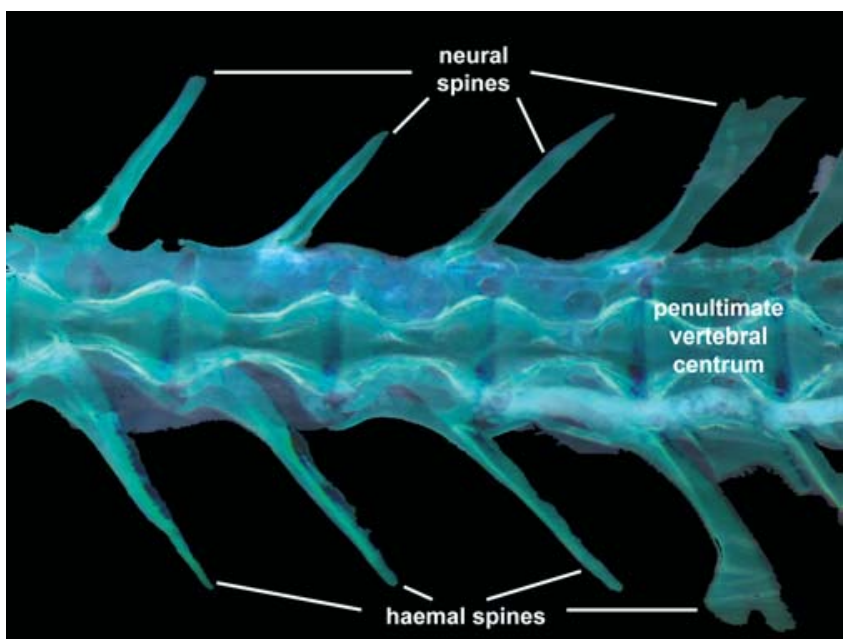

Fig. 4. Detail of the region anterior to the compound caudal centrum of Aspidoras psammatides, paratype, MNRJ 21709, $22.6 \mathrm{~mm} \mathrm{SL}$, showing neural and haemal spines close to its respective post-zygapophyses.

Dorsal fin roughly triangular; its origin just posterior to third dorsolateral body plate. Dorsal spine shorter than first five branched rays. Distal tip of spine with minute-segmented unossified portion. Anterior and posterior border of dorsal spine smooth. Dorsal-fin rays I,8 in all specimens examined. Adipose fin roughly triangular; its origin separated from base of last dorsal-fin ray by seven to eight dorsolateral body plates. Anal fin roughly ovoid; its origin located just posterior to 13 th to 16 th ventrolateral body plates, at vertical through anterior margin of adipose-fin spine. Anal-fin rays ii, $5, \mathrm{i}$ *; one specimen (MNRJ 21710, $24.6 \mathrm{~mm} \mathrm{SL}$ ) ii,4,i. Pectoral fin roughly rounded; its origin located just posterior to gill opening. Ossified portion of pectoral spine shorter than first five branched rays. Distal tip of spine with minute-segmented unossified portion. Pectoral spine with well-developed serrations along entire posterior border. Pectoral-fin rays I,9* (27) or I,10 (25). Pelvic fin ellipsoid; its origin just below second ventrolateral body plate, at vertical through base of third branched dorsalfin ray. Pelvic-fin rays i, 5. Caudal fin bilobed; both lobes equal in size. Principal caudal-fin rays i,6/6, $\mathrm{i}^{*}$, one specimen (MNRJ 21711, $27.4 \mathrm{~mm} \mathrm{SL}$ ) i,6/5,i; upper procurrent caudal-fin rays iv; lower procurrent caudal-fin rays iv. All fins with minute odontodes scattered over all rays.

Color in alcohol. Ground coloration of head light brown to yellowish white. Several chromatophores clustered in minute brown dots scattered over dorsal and lateral surface of head. Dots more concentrated on posterodorsal portion of opercle and on side of snout forming discrete stripe from anteroventral region of orbit to snout tip. Larger individuals (up to $26.4 \mathrm{~mm}$ SL) with dots grouped in small blotches. Small specimens with scattered minute brown blotches on anterior portion of snout. All barbels yellowish white; few chromatophores present on barbels in some individuals.

Ground color of trunk light brown to yellowish white. Dif- 


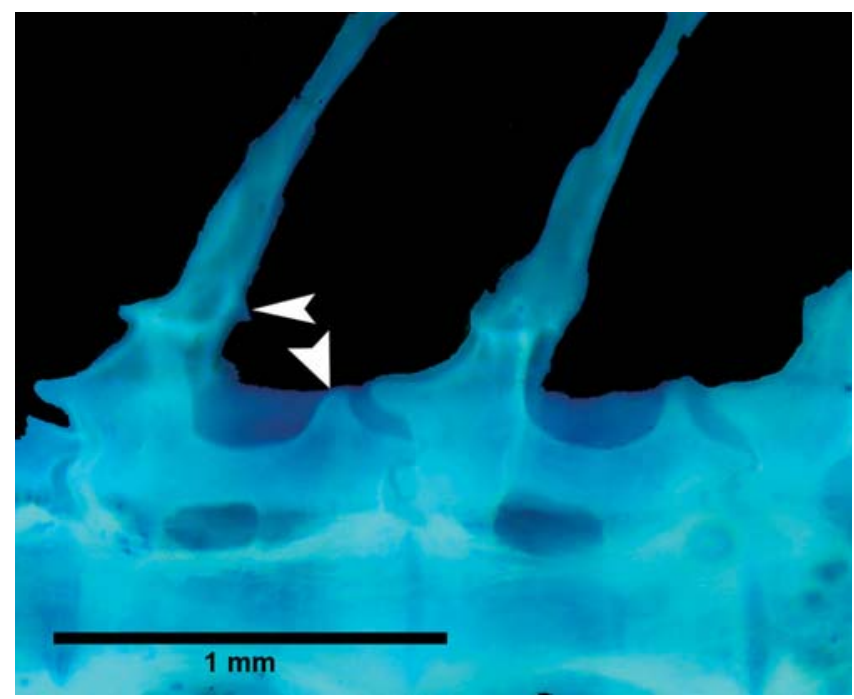

Fig. 5. Detail of the dorsal region of precaudal vertebrae of Aspidoras psammatides, paratype, MNRJ 21709, 22.6 mm SL, showing their post-zygapophyses not connected with respective neural spine (arrows).

fuse brown blotch on middle region of cleithrum. Minute dark brown dots scattered over entire surface of trunk; more concentrated on dorsal region. Dots clustered around bases of dorsal spine, last dorsal-fin ray and adipose-fin spine, respectively. Small diffuse brown blotches along lateral junction of body plates, from cleithrum to caudal peduncle. Blotches varying in number from five to (more commonly) eight blotches. Ventral surfaces of body yellowish white.

Interradial membrane of all fins hyaline. Dorsal fin with few chromatophores scattered on dorsal spine and first two to three adjacent rays, scarcely present on their tips. Ground color of anal-fin rays yellowish white. Some individuals with sparce chromatophores on base of rays. Few chromatophores scattered over adipose-fin spine; some individuals with chromatophores also on adipose-fin membrane adjacent to spine and on its apex. All pectoral-fin rays and spine yellowish white. Larger specimens with sparse chromatophores on first two branched rays. Pelvic-fin rays hyaline. Caudal-fin rays yellowish white with several chromatophores clustered in three-four patches restricted to the three outermost rays of both lobes. Color in life very similar to that of preserved specimens.

Sexual dimorphism. As usual for corydoradines (e.g. Nijssen \& Isbrücker, 1980: 130; Britto, 2003: 142, fig. 23), males of Aspidoras psammatides possess a lanceolated papilla. However, relatively few males show a well-developed papilla, which made the determination of sex in most specimens more difficult than with other Aspidoras species (e.g. Britto, 1998, 2000, Lima \& Britto, 2001, Britto et al., 2002).

Habitat and ecological notes. The species is known from affluents of the rio São José, one of the main tributaries of the upper course of rio Paraguaçu, which has several relatively small tributaries entering its right margin. The species was collected in four of these tributaries, rio Roncador, rio Capivara, rio Ribeirão and rio Caldeirão. The rio São José and its tributaries are all blackwater rivers. The type locality of Aspidoras psammatides, rio Caldeirão, has sandy and rocky bottom, with little amount of riparian and submerged vegetation.

Distribution. Aspidoras psammatides is known only from tributaries of the upper rio Paraguaçu, a coastal river basin from eastern Brazil (Fig. 6)

Etymology. Psammatides, after "Psammatos psammatides", "the sand sorcerer", a character of J.R.R. Tolkien's book "Roverandom", from the Greek psammos, sand, and ides, son of. In allusion to the sand-dwelling behavior of the species. A noun in apposition.

\section{Discussion}

Aspidoras psammatides is remarkable among its congeners by displaying a suite of characters apparently related to paedomorphosis. Some of them are shared with Aspidoras velites, such as dorsolateral body plates not touching their counterparts dorsally and infraorbital bones with reduced flanges, nearly restricted to the laterosensory canal. Despite possessing the predorsal area naked as in A. velites, the condition found in $A$. psammatides is not as extreme as that found in the latter species, where not only the anterior dorsolateral plates but also the parieto-supraoccipital process and the

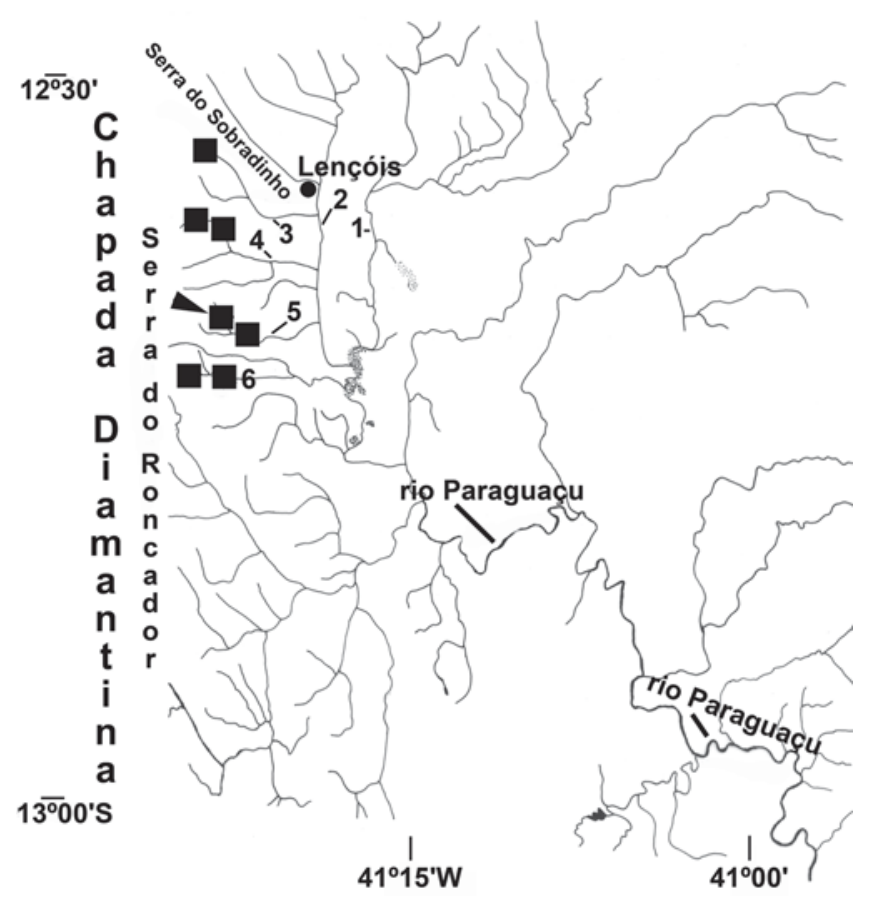

Fig. 6. Map of upper course of rio Paraguaçu showing the distribution of Aspidoras psammatides (squares). 1: rio Santo Antônio; 2: rio São José; 3: rio Ribeirão; 4: rio Capivara; 5: rio Caldeirão; 6: rio Roncador; arrow: type locality. 
nuchal plate are reduced (Britto et al., 2002). Specimens up to $26.4 \mathrm{~mm}$ SL of A. psammatides possess dorsolateral body plates not touching their counterparts at the preadipose area, a condition shared with $A$. velites of all sizes. As discussed in Britto et al. (2002: 733, 735) and Britto (2003: 128-129), infraorbital bones with reduced flanges are unusual in corydoradines and only known previously in Corydoras pygmaeus, $C$. hastatus, C. panda, and Aspidoras velites.

Another exclusive character that is apparently paedomorphic for Aspidoras psammatides is the post-zygapophyses of precaudal vertebrae not showing dorsal expansions connected with their respective neural spines. This condition is observed, among the remaining callichthyids, only in juvenile specimens. During the ontogeny the post-zygapophyses develop a laminar outgrowth that fuses to the respective neural spine. An additional, although not reductive, autapomorphy for the species is the presence of four or five caudal vertebra, anterior to compound caudal centrum, with neural and haemal spines placed posteriorly, close to post-zygapophyses, whereas in the remaining callichthyids invariably only the three latter vertebrae show the neural spines placed posteriorly.

Among Aspidoras species, A. psammatides shares a narrow interorbital distance and poorly-developed color pattern with A. maculosus, a species described from the headwaters of the rio Itapicuru, an eastern coastal drainage immediately north to the rio Paraguaçu basin in Bahia, Brazil. Aspidoras maculosus is only known from its poorly preserved and faded type series, which were not examined in the present study. However, examination of Ellis'(1913: pl. XXVI, fig. 3) illustration, which depicts the pigmentation of the (then) recently collected A. maculosus holotype, plus recent pictures of the same specimen, allows a comparison between both species. Aspidoras psammatides is clearly distinct from A. maculosus in at least two characters, viz., the color pattern, which consists, respectively, in minute scattered blotches on dorsal region of head and body, but grouped in small, irregular blotches along lateral body plate junction ( $v s$. three longitudinal series of small rounded blotches, the more conspicuous one along lateral body plate junction), and dorsolateral body plates not touching their counterparts dorsally, leaving a small predorsal naked area ( $v s$. dorsolateral body plates touching their counterparts dorsally, leaving no naked predorsal area). In addition, Aspidoras maculosus shows an interorbital distance (28.6 - $33.1 \% \mathrm{HL}$ ) somewhat larger than in A. psammatides (19.9 $27.8 \% \mathrm{HL}$ ).

The low degree of development of the pigmentation found in Aspidoras psammatides is unique among Aspidoras species and recalls the color pattern observed in several unrelated catfish groups such as some African Amphiliidae (e.g. Leptoglanis spp., Psamphyletria, Dolicamphilius, Tetracamphilius, and Zaireichthys; Skelton, 1993: 219-220; Roberts, 2003), South American Trichomycteridae (e.g. Microcambeva spp.; Costa \& Bockmann, 1994; Costa et al., 2004), and also some Asiatic Cypriniformes (e.g., Acanthopsoides, Cobitidae; Siebert, 1991) and North American Perciformes ("sand darters", Ammocrypta spp.; Page \&
Burr, 1991: 288). Apparently these fishes share a lifestyle that involves dwelling in riverine sand bars, where they spend part of their time partially burrowed in the sand. At this time, we know little about Aspidoras psammatides habits other than it lives at sandy stretches of rivers, but the combination of its color pattern, elongate body and relatively high-positioned eyes suggest that it might have a similar mode of life as the afore-mentioned fishes.

\section{Acknowledgements}

We are indebted to M. Ghazzi and A. Netto-Ferreira (MNRJ) for suggestions on the manuscript. P. Willink (FMNH) kindly provided measurements from holotype and paratypes of Aspidoras maculosus deposited at that institution. A. NettoFerreira helped with the photographs of bones, suggesting their use in "high-contrast negative". MRB received financial support from CNPq (grant 300189/03-6); FCTL receives financial support from FAPESP (grant 01/14449-2). ACAS received financial support from CAPES/ PICDT-UEFS and from Projeto Nordeste de Pesquisa, CNPq. MRB and FCTL are participants of ACSI (All Catfish Species Inventory Project).

\section{Literature cited}

Aquino, A. E. \& S. A. Schaefer. 2002. The temporal region of the cranium of loricarioid catfishes (Teleostei: Siluriformes): Morphological diversity and phylogenetic significance. Zoologischer Anzeiger, 241: 223-244.

Arratia, G. \& M. Gayet. 1995. Sensory canals and related bones of tertiary siluriform crania from Bolivia and North America and comparison with recent forms. Journal of Vertebrate Paleontology, 15: 482-505.

Britto, M. R. 1998. Two new species of the genus Aspidoras (Siluriformes: Callichthyidae) from Central Brazil. Ichthyological Exploration of Freshwaters, 8: 359-368.

Britto, M. R. 2000. Aspidoras depinnai (Siluriformes: Callichthyidae), a new species from northeastern Brazil. Copeia, 2000: 1048-1055.

Britto, M. R. 2003. Phylogeny of the subfamily Corydoradinae Hoedeman, 1952 (Siluriformes: Callichthyidae), with a definition of its genera. Proceedings of the Academy of Natural Sciences of Philadelphia, 153: 119-154.

Britto, M. R. \& F. C. T. Lima. 2003. Corydoras tukano, a new species of corydoradine catfish from the rio Tiquié, upper rio Negro basin, Brazil (Ostariophysi: Siluriformes: Callichthyidae). Neotropical Ichthyology, 1: 83-91.

Britto, M. R., F. C. T. Lima \& C. R. Moreira. 2002. Aspidoras velites, a new catfish from the upper rio Araguaia basin, Brazil (Teleostei: Siluriformes: Callichthyidae). Proceedings of the Biological Society of Washington, 115: 727-736.

Campanario, C. M. \& M. C. C. de Pinna. 2000. A new species of the primitive trichomycterid subfamily Copionodontinae from northeastern Brazil (Teleostei: Trichomycteridae). Ichthyological Exploration of Freshwaters, 11: 369-375. 
Costa, W. J. E. M. \& F. A. Bockmann. 1994. A new genus and species of Sarcoglanidinae (Siluriformes: Trichomycteridae) from southeastern Brazil, with a re-examination of subfamilial phylogeny. Journal of Natural History, 28: 715-730.

Costa, W. J. E. M., S. M. Q. Lima \& C. R. S. F. Bizerril. 2004. Microcambeva ribeirae sp. n. (Teleostei: Siluriformes: Trichomycteridae): a new sarcoglanidine catfish from the Rio Ribeira do Iguape basin, southeastern Brazil. Zootaxa, 563: 1-10.

Ellis, M. D. 1913. The plated nematognaths. Annals of the Carnegie Museum, 8: 384-413.

Lima, F. C. T. \& M. R. Britto. 2001. New catfish of the genus Aspidoras (Siluriformes: Callichthyidae) from the upper Rio Paraguai system in Brazil. Copeia, 2001: 1010-1016.

Lima, F.C.T. \& P. Gerhard. 2001. A new Hyphessobrycon (Characiformes: Characidae) from Chapada Diamantina, Bahia, Brazil, with notes on its natural history. Ichthyological Exploration of Freshwaters, 12: 105-114.

Lundberg, J. G. 1970. The evolutionary history of North American catfishes, Family Ictaluridae. Unpublished Ph.D. Dissertation, The University of Michigan, Ann Arbor. xiii +524p.

Malabarba, L. R., F. C. T. Lima \& S. H. Weitzman. 2004. A new species of Kolpotocheirodon (Teleostei: Characidae: Cheirodontinae: Compsurini) from Bahia, northeastern Brazil, with a new diagnosis of the genus. Proceedings of the Biological Society of Washington, 117: 317-329.

Nijssen, H. \& I. J. H. Isbrücker. 1976. The South American plated catfish genus Aspidoras R. von Ihering, 1907, with descriptions of nine new species from Brazil (Pisces, Siluriformes, Callichthyidae). Bijdragen tot de Dierkunde, 46: 107-131.

Nijssen, H. \& I. J. H. Isbrücker. 1980. Aspidoras virgulatus n. sp., a plated catfish from Espírito Santo, Brazil (Pisces, Siluriformes, Callichthyidae). Bulletin Zoologisch Museum, Universiteit van Amsterdam, 7: 133-138.

Page, L. M. \& B. M. Burr. 1991. A field guide to Freshwater Fishes. North America north of Mexico. Boston, Houghton Mifflin Co., 432 pp.

de Pinna, M. C. C. 1992. A new subfamily of Trichomycteridae (Teleostei, Siluriformes), lower loricarioid relationships and a discussion on the impact of additional taxa for phylogenetic analysis. Zoological Journal of the Linnean Society, 106: 175-229.

Reis, R. E. 1997. Revision of the neotropical catfish genus Hoplosternum (Ostariophysi, Siluriformes, Callichthyidae), with the description of two new genera. Ichthyological Exploration of Freshwaters, 7: 299-326.
Reis, R. E. 1998. Anatomy and phylogenetic analysis of the neotropical callichthyid catfishes (Ostariophysi, Siluriformes). Zoological Journal of the Linnaean Society, 124: $105-168$.

Reis, R. E., S. O. Kullander \& C. J. Ferraris. 2003. Check List of the Freshwater Fishes of South and Central America. Edipucrs, Porto Alegre. 729p.

Roberts, T. R. 2003. Systematics and osteology of Leptoglaninae a new subfamily of the African catfish family Amphiliidae, with descriptions of three new genera and six new species. Proceedings of the California Academy of Sciences, 54: 81-132.

Schaefer, S. A. 1988. Homology and evolution of the opercular series in the loricarioid catfishes (Pisces: Siluroidei). Journal of Zoology, 214: 81-93.

Schaefer, S. A. 1998. Conflict and resolution: impact of new taxa on phylogenetic studies of the Neotropical cascudinhos (Siluroidei: Loricariidae). Pp. 375-400. In: Malabarba, L. R., R. E. Reis, R. P. Vari, Z. M. S. Lucena \& C. A. S. Lucena (Eds.). Phylogeny and classification of Neotropical fishes. Edipucrs, Porto Alegre. 603p.

Schaefer, S. A. \& A. Aquino. 2000. Postotic laterosensory canal and pterotic branch homology in catfishes. Journal of Morphology, 246: 212-227.

Siebert, D. J. 1991. Revision of Acanthopsoides Fowler, 1934 (Cypriniformes: Cobitidae), with the description of new species. Japanese Journal of Ichthyology, 38: 97-114.

Skelton, P. 1993. A complete guide to the freshwater fishes of southern Africa. Southern Books Publishers, Harare. 388p.

Taylor, W. R. \& E. C. Van Dyke. 1985. Revised procedures for staining and clearing small fishes and other vertebrates for bone and cartilage study. Cybium, 9: 107-119.

Vari, R. P. \& L. R. Malabarba. 1998. Neotropical Ichthyology: an overview. Pp. 1-11. In: Malabarba, L. R., R. E. Reis, R. P. Vari, Z. M. S. Lucena \& C. A. S. Lucena (Eds.). Phylogeny and classification of Neotropical fishes. Edipucrs, Porto Alegre. 603p.

Weitzman, S. H. \& M. H. Balph. 1979. Some phylogenetic implications of a discovery of Aspidoras pauciradiatus (Pisces: Siluriformes: Callichthyidae) from the rio Negro in Brazil. Proceedings of the Biological Society of Washington, 92: 10-22.

Zanata, A.M. \& A. Akama. 2004. Myxiops aphos, new characid genus and species (Characiformes: Characidae) from the rio Lençóis, Bahia, Brazil. Neotropical Ichthyology, 2: 45-54.

Received May 2005 Accepted June 2005 